\title{
Effect of Mechanical and Chemical Scarification on Germination of Dodder (Cuscuta campestris Yunck.) Seed
}

\author{
A. B. Mustapha', N. A. Gworgwor', B. B. Jakusko' ${ }^{1}$ \\ ${ }^{1}$ Department of Crop Production and Horticulture, Modibbo Adama University of Technology, Yola, Nigeria \\ ${ }^{2}$ Department Crop Science, University of Maiduguri, Maiduguri, Nigeria \\ Email: aliyuaim@yahoo.co.uk
}

Received 15 July 2015; accepted 21 August 2015; published 25 August 2015

\begin{abstract}
Experiments were carried out to evaluate the effect of seed treatment on germination of Cuscuta campestris. This may provide the possible ways to overcome the problem of dormancy in Cuscuta campestris. The experiments were conducted in the Laboratory of Crop Production and Horticulture, Modibbo Adama University of Technology, Yola, Adamawa State, Nigeria, using mechanical scarification and tetraoxosulphate (VI) acid $\left(\mathrm{H}_{2} \mathrm{SO}_{4}\right)$. For the mechanical scarification the treatments were unscarified, scarified using sandpaper and scarified using gravel arranged in a completely randomized design (CRD) and replicated four times. For the tetraoxosulphate (VI) acid $\left(\mathrm{H}_{2} \mathrm{SO}_{4}\right)$ scarification, the treatment of control, 9:1, 7:3, 1:1, 4:6, 3:7, 2:8 and 1:9 $\mathrm{H}_{2} \mathrm{SO}_{4}$ were laid out in a Split plot design and replicated three times. The mechanical scarification was not significant ( $P$ $\leq$ 0.05), a rapid increase of germination from day 3 to day 9 was observed, and the highest rate of germination percentage $(14 \%-22 \%)$ obtained on day 9 . Tetraoxosulphate (VI) acid treatment of 4:6 concentrations significantly gave the highest $C$. campestris seeds germination percentage $(40.07 \%)$ compared with the rest of the treatments, while the time of soaking the seeds in the tetraoxosulphate (VI) acid showed that soaking the seeds for 1 minute significantly gave the highest percentage germination (39.98\%) of $C$. campestris compared with the 3 and 5 minutes soaking treatments. It can be concluded that sulphuric acid of 4:6 concentrations treatments has the potentiality to break dormancy of $C$. campestris seeds.
\end{abstract}

\section{Keywords}

Dormancy, Scarification, Germination, Cuscuta campestris

\section{Introduction}

Dodders (Cuscuta spp. Family: Cuscutaceae) are distributed worldwide [1]. They have very low host specificity and attack many plants simultaneously. Although dicotyledons are preferred as hosts, attacks on monocotyledons have been reported by [2]. Cuscuta campestris is a parasitic annual plant that infests many food crops, ornamen- 
tal native plants and weeds. The impact of Cuscuta campestris ranges from moderate to severe reductions in growth of the host plant and in some instances may result in complete loss of vigor and death as reported by [3]. Tomato crop vigor is lowered due to Cuscuta infestation and tomato production yield is reduced by $25 \%$ to $75 \%$ [4]. It has been shown that field dodder infestation reduces carrot (Daucuscarota L.) yield by $70 \%$ - $90 \%$ and also dodder weakens alfalfa, reduces its stand and can reduce yield of forage seed production by more than $50 \%$ [5].

Germination is generally low and poor in annual holoparasites such as Cuscuta. Germination increases by scarification of seeds of many Cuscuta species [3] [6]. [7] soaked the seeds in concentrated $\mathrm{H}_{2} \mathrm{SO}_{4}$; while [8] scarified the seeds with sand paper. Cuscuta campestris germination characteristics are not adequately reported in Nigeria, especially in Adamawa State. With the incidence of the wide spread of $C$. campestris in the Northeast region and in Adamawa State in particular [2], it has become imperative to undertake a study on its biology. Therefore, this study was aimed at investigating the effect of chemical and mechanical means of breaking seed dormancy of C. campestris.

\section{Materials and Methods}

Two different experiments were conducted in the Laboratory of the Department of Crop Production and Horticulture, Modibbo Adama University of Technology, Yola, Adamawa State, Nigeria. These experiments were on mechanical scarification and concentrated tetraoxosulphate (VI) acid $\left(\mathrm{H}_{2} \mathrm{SO}_{4}\right)$. Mechanical scarification was achieved by subjecting Cuscuta campestris seeds to only three methods of scarification as follows: unscarified, scarified using sandpaper and scarified using small sand gravels of an average of $4.4 \mathrm{~mm}$ in diameter. Sandpaper scarification was achieved in the following manner as described by Hutchison and Ashton (1979). Rubber paddles was attached to the shaft of a Virtus 45 hamogenizer from which the blades had been removed. Paddles were cut from rubber and attached to the shaft with epoxy cement. The shaft was inserted into a plastic jar line with sandpaper. Seeds were added and spun by the paddle. Small sand gravels were used by taking dried seeds and placed in metal container with gravels. The container was shaken vigorously for 3 to 5 minutes to enable the gravels cause abrase of the seed epicarp. The seeds were taken out of the gravel, dusted and then placed in Petridishes with laden Whatman filter papers $(9.0 \mathrm{~cm})$. One hundred and sixty seeds were placed in each of a set of ten Petri-dishes. The treatments were arranged in a completely randomized design (CRD) and replicated four times. Distilled water was added at 24 hour intervals and germination of the seeds was observed and recorded. Tetraoxosulphate (VI) acid $\left(\mathrm{H}_{2} \mathrm{SO}_{4}\right)$ was used at different concentrations as treatments for 1,3 and 5 minutes as follows: $1 \mathrm{~mol} \mathrm{H}_{2} \mathrm{SO}_{4}$ (90\%), 3 mol H $\mathrm{SO}_{4}$ (70\%), 5 mol H $\mathrm{SO}_{4}(50 \%), 6 \mathrm{~mol} \mathrm{H}_{2} \mathrm{SO}_{4}(40 \%), 7 \mathrm{~mol} \mathrm{H}_{2} \mathrm{SO}_{4}(30 \%)$, $8 \mathrm{~mol} \mathrm{H}_{2} \mathrm{SO}_{4}(20 \%)$ and $9 \mathrm{~mol} \mathrm{H}_{2} \mathrm{SO}_{4}(10 \%)$ with distilled water as the control. One hundred and sixty eight seeds of Cuscuta were taken and immersed in concentrated grade $\mathrm{H}_{2} \mathrm{SO}_{4}$ in a conical flask for 1 minute [9]. One hundred and sixty eight seeds each were placed immediately on Wattman filter paper soaked in distilled water and laden on $9 \mathrm{~cm}$ diameter Petri-dish and replicated times. Similar procedure was repeated with the same acid concentrations for 3 and 5 minutes, respectively. Similar numbers of seeds were soaked in distilled water for the same period as control. Each of the fifteen treatments was replicated three times in a Split plot design with time as the main plot effect and $\mathrm{H}_{2} \mathrm{SO}_{4}$ as the subplot effect.

Data were collected on germination percentage (\%) of Cuscuta. Cuscuta campestris that germinated days after placing on Petri-dish were observed at an interval of 3 days for 2 weeks. Data collected were analyzed using analysis of variance (ANOVA) as described by [10]. Where ANOVA shows significance, mean separation was done using Duncan’s multiple range test (DMRT) at 5\% level of probability [11].

\section{Results}

\section{Effects of Tetraoxosulphate (VI) Acid $\left(\mathrm{H}_{2} \mathrm{SO}_{4}\right)$ and Soaking Time on Germination of Cuscuta campestris}

The effects of tetraoxosulphate (VI) acid, soaking time and the interaction between tetraoxosulphate (VI) acid and soaking time on the germination of $C$. campestris seed was significant on day 3, 6, 9 and the combined mean for Trials I and II with the exception of day 6 in the Trial II and soaking time in the Trial I of day 6, Trial II of day 3, 6, 9 and the combined mean of day 3 (Table 1). On day 3 of Trial I, tetraoxosulphate (VI) acid 
Table 1. Effect of tetraoxosulphate (VI) acid and soaking time on percentage germination of Cuscuta campestris.

\begin{tabular}{|c|c|c|c|c|c|c|c|c|c|}
\hline \multirow[b]{3}{*}{ Treatment } & \multicolumn{9}{|c|}{ Germination percentage (\%) } \\
\hline & \multicolumn{3}{|c|}{ Day 3} & \multicolumn{3}{|c|}{ Day 6} & \multicolumn{3}{|c|}{ Day 9} \\
\hline & Trial I & Trial II & Mean & Trial I & Trial II & Mean & Trial I & Trial II & Mean \\
\hline \multicolumn{10}{|l|}{$\begin{array}{l}\text { Tetraoxosulphate } \\
\text { (VI) Acid(TOS) }\end{array}$} \\
\hline Control & $3.51^{\mathrm{a} 1}$ & $1.13^{\mathrm{ab}}$ & $2.32^{\mathrm{a}}$ & $4.70^{\mathrm{a}}$ & $1.32^{\mathrm{a}}$ & $3.01^{\mathrm{a}}$ & $75.99^{\mathrm{a}}$ & $3.65^{\mathrm{a}}$ & $39.82^{\mathrm{a}}$ \\
\hline 9:1 $\mathrm{H}_{2} \mathrm{SO}_{4}$ & $0.33^{\mathrm{c}}$ & $0.40^{\mathrm{b}}$ & $0.36^{\mathrm{c}}$ & $0.46^{\mathrm{e}}$ & $0.73^{\mathrm{a}}$ & $0.60^{\mathrm{d}}$ & $57.14^{\mathrm{c}}$ & $0.99^{\mathrm{b}}$ & $28.07^{\mathrm{c}}$ \\
\hline $7: 3 \mathrm{H}_{2} \mathrm{SO}_{4}$ & $0.47^{c}$ & $0.99^{\mathrm{ab}}$ & $0.73^{c}$ & $0.73^{\mathrm{e}}$ & $0.86^{\mathrm{a}}$ & $0.80^{\text {cd }}$ & $74.40^{\mathrm{a}-\mathrm{c}}$ & $1.06^{\mathrm{b}}$ & $37.73^{\mathrm{ab}}$ \\
\hline $1: 1 \mathrm{H}_{2} \mathrm{SO}_{4}$ & $0.40^{\mathrm{c}}$ & $1.39^{\mathrm{a}}$ & $0.90^{\mathrm{bc}}$ & $0.60^{\mathrm{e}}$ & $0.93^{\mathrm{a}}$ & $0.76^{\mathrm{d}}$ & $72.55^{\mathrm{a}-\mathrm{c}}$ & $0.79^{\mathrm{b}}$ & $36.67^{\mathrm{a}-\mathrm{c}}$ \\
\hline $4: 6 \mathrm{H}_{2} \mathrm{SO}_{4}$ & $1.79^{\mathrm{b}}$ & $0.93^{\mathrm{ab}}$ & $1.36^{\mathrm{b}}$ & $2.58^{\mathrm{b}}$ & $0.93^{\mathrm{a}}$ & $1.75^{\mathrm{b}}$ & $78.68^{\mathrm{a}}$ & $5.62^{\mathrm{a}}$ & $40.07^{\mathrm{a}}$ \\
\hline $3: 7 \mathrm{H}_{2} \mathrm{SO}_{4}$ & $0.79^{c}$ & $0.79^{\mathrm{ab}}$ & $0.79^{\mathrm{c}}$ & $1.92^{\mathrm{bc}}$ & $0.73^{\mathrm{a}}$ & $1.33^{\mathrm{bc}}$ & $67.19^{\mathrm{a}-\mathrm{c}}$ & $1.59^{\mathrm{b}}$ & $34.39^{\mathrm{a}-\mathrm{c}}$ \\
\hline $2: 8 \mathrm{H}_{2} \mathrm{SO}_{4}$ & $0.66^{\mathrm{c}}$ & $0.66^{\mathrm{ab}}$ & $0.66^{\mathrm{c}}$ & $0.99^{\mathrm{de}}$ & $0.66^{\mathrm{a}}$ & $0.83^{\mathrm{cd}}$ & $66.73^{\mathrm{a}-\mathrm{c}}$ & $0.80^{\mathrm{b}}$ & $33.76^{\mathrm{a}-\mathrm{c}}$ \\
\hline $1: 9 \mathrm{H}_{2} \mathrm{SO}_{4}$ & $0.53^{\mathrm{c}}$ & $0.66^{\mathrm{ab}}$ & $0.60^{\mathrm{c}}$ & $1.66^{\mathrm{cd}}$ & $1.19^{\mathrm{a}}$ & $1.42^{\mathrm{b}}$ & $59.86^{\mathrm{bc}}$ & $2.32^{\mathrm{ab}}$ & $31.09^{\mathrm{bc}}$ \\
\hline $\mathrm{SE}( \pm)$ & 0.23 & 0.34 & 0.22 & 0.24 & 0.34 & 0.22 & 4.66 & 0.80 & 3.32 \\
\hline \multicolumn{10}{|l|}{ Soaking time $(T)$} \\
\hline 1 minute & $1.61^{\mathrm{a}}$ & $0.67^{\mathrm{a}}$ & $1.14^{\mathrm{a}}$ & $2.58^{\mathrm{a}}$ & $0.87^{\mathrm{ab}}$ & $1.73^{\mathrm{a}}$ & $78.26^{\mathrm{a}}$ & $1.69^{\mathrm{a}}$ & $39.98^{\mathrm{a}}$ \\
\hline 3 minutes & $0.60^{\mathrm{b}}$ & $1.22^{\mathrm{a}}$ & $0.91^{\mathrm{a}}$ & $1.12^{\mathrm{b}}$ & $1.22^{\mathrm{a}}$ & $1.17^{\mathrm{a}}$ & $64.12^{\mathrm{a}}$ & $1.79^{\mathrm{a}}$ & $32.95^{\mathrm{b}}$ \\
\hline 5 minutes & $0.97^{\mathrm{ab}}$ & $0.72^{\mathrm{a}}$ & $0.85^{\mathrm{a}}$ & $1.42^{\mathrm{b}}$ & $0.67^{\mathrm{b}}$ & $1.04^{\mathrm{b}}$ & $64.83^{\mathrm{a}}$ & $1.27^{\mathrm{a}}$ & $33.05^{\mathrm{b}}$ \\
\hline $\mathrm{SE}( \pm)$ & 0.38 & 0.55 & 0.36 & 0.39 & 0.55 & 0.36 & 7.62 & 2.28 & 3.00 \\
\hline Interaction (TOSXT) & $*_{2}$ & Ns & Ns & * & Ns & * & Ns & Ns & * \\
\hline
\end{tabular}

${ }^{1}$ Means in the same column followed by the same letter(s) are not significantly different from each other according to Duncun’s Multiple Range Test (DMRT) at $5 \%$ level of probability. *Significantly different at $5 \%$ level of probability. NS = not significantly different at $5 \%$ level of probability.

treatments significantly had the lowest percentage germination of $C$. campestris seeds compared with the control (3.51\%), while in Trial II, $1: 1 \mathrm{H}_{2} \mathrm{SO}_{4}$ treatment significantly had higher germination percentage of $1.39 \mathrm{C}$. campestris seeds which were at par with all the other treatments except 9:1 $\mathrm{H}_{2} \mathrm{SO}_{4}$ treatment (Table 1). However, when the two trials were combined, the control treatment recorded the highest germination percentage of $2.32 \mathrm{C}$. campestris seeds compared with all the tetraoxosulphate (VI) acid treatments (Table 1). Similarly, on day 6 of Trial I, all the tetraoxosulphate (VI) acid treatments significantly had the lowest germination of C. campestris seeds compared with the control treatment, while in Trial II no significant difference was observed (Table 1). However, when the two trials were combined the control treatment had the highest germination percentage of 3.01 C. campestris seeds compared with the tetraoxosulphate (VI) acid treatments (Table 1). On day 9 in Trial I, tetraoxosulphate (VI) acid treatment of 4:6 $\mathrm{H}_{2} \mathrm{SO}_{4}$ and control treatment significantly gave the highest germination percentage of 78.68 and 75.99 Cuscuta seeds than the 9:1 $\mathrm{H}_{2} \mathrm{SO}_{4}$ and 1:9 $\mathrm{H}_{2} \mathrm{SO}_{4}$ treatment, but was comparable with the rest of the tetraoxosulphate (VI) acid treatments (Table 1). However, in Trial II the control and 4:6 $\mathrm{H}_{2} \mathrm{SO}_{4}$ treatments recorded the highest germination percentage of $3.65 \%$ and $5.62 \%$ C. campestris seeds respectively, which were at par with 1:9 $\mathrm{H}_{2} \mathrm{SO}_{4}$ treatment. The combined mean for both trials similarly, showed that the 4:6 $\mathrm{H}_{2} \mathrm{SO}_{4}$ and the control recorded significantly higher germination percentage of 40.07 and 39.82, respectively C. campestris seeds when compared to the 9:1 $\mathrm{H}_{2} \mathrm{SO}_{4}$ and $1: 9 \mathrm{H}_{2} \mathrm{SO}_{4}$ treatments but were at par with the other $\mathrm{H}_{2} \mathrm{SO}_{4}$ treatments (Table 1).

The soaking time revealed that in Trial I on day 3 and 6 the 1 minute soaking treatment significantly had the highest germination of $C$. campestris seeds than the 3 and 5 minutes soaking treatments (Table 1). However, in Trial II no significant germination among the treatment was observed in all the days. On day 6 of the combined mean the 1 minute and 3 minutes soaking treatments significantly had the highest germination percentage of 1.73 and $1.17 \mathrm{C}$. campestris seeds compared with the 5 minutes treatment respectively, while on day 9 the combined mean of 1 minute soaking treatment significantly had the highest germination percentage of 39.98 C. campestris 
seeds compared with the 3 and 5 minutes treatments (Table $\mathbf{1}$ ).

The interaction between tetraoxosulphate (VI) acid treatments and the soaking time was significant on $C$. campestris seeds germination only at day 3 and 6 of Trials I, though for the combined only on day 6 and 9 significance were only observed (Table 1).

The interaction between tetraoxosulphate (VI) acid and soaking time showed that the germination of Cuscuta campestris seeds was significantly affected in Trial I on day 3 (Table 2). All the interactions between $\mathrm{H}_{2} \mathrm{SO}_{4}$ treatments and soaking time had significantly the lowest germination of $C$. campestris seeds compared with the control treatment (Table 2).

Germination of Cuscuta campestris seeds were significantly affected by the interaction between tetraoxosulphate (VI) acid and soaking time in Trial I on day 6 (Table 3). The result shows that all the means of the interactions had significantly the lowest germination of $C$. campestris seeds compared with the control at 1 minute, 3 and 5 minutes soaking time.

Similarly, the 4:6 and 3:7 $\mathrm{H}_{2} \mathrm{SO}_{4}$ treatments at 1 minute soaking time had the highest germination of Cuscuta seeds compared with the rest of the interaction treatments (Table 3).

Table 4 shows that the germination of $C$. campestris seeds was significantly affected by the interaction between tetraoxosulphate (VI) acid and soaking time on day 6 of the combined mean of Trials I and II. The result reveals that all the interaction means had significantly lowest germination of $C$. campestris seeds with the

Table 2. Interaction effects between tetraoxosulphate (VI) acid $\left(\mathrm{H}_{2} \mathrm{SO}_{4}\right)$ and soaking time on percentage germination of Cuscuta campestris at day 3 in Trial I.

\begin{tabular}{|c|c|c|c|}
\hline \multirow{2}{*}{ Treatment } & \multicolumn{3}{|c|}{ Soaking time (minutes) } \\
\hline & 1 & 3 & 5 \\
\hline Control & $4.76^{\mathrm{a}}$ & $2.38^{\mathrm{cd}}$ & $3.37^{\mathrm{b}}$ \\
\hline 9:1 $\mathrm{H}_{2} \mathrm{SO}_{4}$ & $0.40^{\mathrm{g}-\mathrm{j}}$ & $0.00^{\mathrm{h}-\mathrm{j}}$ & $0.60^{f-j}$ \\
\hline $7: 3 \mathrm{H}_{2} \mathrm{SO}_{4}$ & $0.80^{\mathrm{e}-\mathrm{g}}$ & $0.20^{\mathrm{g}-\mathrm{j}}$ & $0.40^{g-j}$ \\
\hline $1: 1 \mathrm{H}_{2} \mathrm{SO}_{4}$ & $0.40^{\mathrm{g}-\mathrm{j}}$ & $0.80^{\mathrm{e}-\mathrm{g}}$ & $0.00^{\mathrm{h}-\mathrm{j}}$ \\
\hline $4: 6 \mathrm{H}_{2} \mathrm{SO}_{4}$ & $2.98^{\mathrm{bc}}$ & $0.40^{\mathrm{g}-\mathrm{j}}$ & $1.99^{c-e}$ \\
\hline $3: 7 \mathrm{H}_{2} \mathrm{SO}_{4}$ & $1.59^{\mathrm{d}-\mathrm{f}}$ & $0.40^{g-j}$ & $0.40^{g-j}$ \\
\hline $2: 8 \mathrm{H}_{2} \mathrm{SO}_{4}$ & $0.80^{\mathrm{e}-\mathrm{g}}$ & $0.20^{g-j}$ & $0.99^{\mathrm{e}-\mathrm{g}}$ \\
\hline $1: 9 \mathrm{H}_{2} \mathrm{SO}_{4}$ & $1.19^{\mathrm{e}-\mathrm{g}}$ & $0.40^{\mathrm{g}-\mathrm{j}}$ & $0.00^{\mathrm{h}-\mathrm{j}}$ \\
\hline \multicolumn{4}{|c|}{$\mathrm{SE}( \pm) 0.38$} \\
\hline
\end{tabular}

Table 3. Interaction effects between tetraoxosulphate (VI) acid $\left(\mathrm{H}_{2} \mathrm{SO}_{4}\right)$ and soaking time on percentage germination of Cuscuta campestris at day 6 in Trial I.

\begin{tabular}{|c|c|c|c|}
\hline \multirow{2}{*}{ Treatment } & \multicolumn{3}{|c|}{ Soaking time (minutes) } \\
\hline & 1 & 3 & 5 \\
\hline Control & $5.75^{\mathrm{a}}$ & $4.56^{\mathrm{b}}$ & $3.77^{\mathrm{b}}$ \\
\hline 9:1 $\mathrm{H}_{2} \mathrm{SO}_{4}$ & $0.80^{\text {def }}$ & $0.00^{\mathrm{ef}}$ & $0.60^{\mathrm{d}-\mathrm{f}}$ \\
\hline $7: 3 \mathrm{H}_{2} \mathrm{SO}_{4}$ & $1.59^{\mathrm{cd}}$ & $0.20^{\mathrm{d}-\mathrm{f}}$ & $2.58^{\mathrm{c}}$ \\
\hline $1: 1 \mathrm{H}_{2} \mathrm{SO}_{4}$ & $0.60^{\mathrm{d}-\mathrm{f}}$ & $0.99^{\text {de }}$ & $0.20^{\mathrm{d}-\mathrm{f}}$ \\
\hline $4: 6 \mathrm{H}_{2} \mathrm{SO}_{4}$ & $3.97^{\mathrm{b}}$ & $0.99^{\text {de }}$ & $2.78^{\mathrm{c}}$ \\
\hline $3: 7 \mathrm{H}_{2} \mathrm{SO}_{4}$ & $3.97^{\mathrm{b}}$ & $0.79^{\mathrm{d}-\mathrm{f}}$ & $1.00^{\mathrm{de}}$ \\
\hline $2: 8 \mathrm{H}_{2} \mathrm{SO}_{4}$ & $1.59^{\text {cd }}$ & $0.40^{\mathrm{d}-\mathrm{f}}$ & $0.99^{\text {de }}$ \\
\hline $1: 9 \mathrm{H}_{2} \mathrm{SO}_{4}$ & $2.38^{\mathrm{c}}$ & $1.00^{\mathrm{de}}$ & $1.59^{\mathrm{cd}}$ \\
\hline \multicolumn{4}{|c|}{$\mathrm{SE}( \pm) 0.46$} \\
\hline
\end{tabular}


exception of 4:6 $\mathrm{H}_{2} \mathrm{SO}_{4}$ and 3:7 $\mathrm{H}_{2} \mathrm{SO}_{4}$ treatment at 1 minute soaking time compared with the control treatment which gave the highest germination (Table 4).

On day 9 , the germination of $C$. campestris seeds was significantly affected by the interaction between tetraoxosulphate (VI) acid and soaking time of the combined mean of Trials I and II (Table 5). The result reveals that all the means of the interaction had significantly the lowest germination of $C$. campestris seeds compared with the control, 3:7 $\mathrm{H}_{2} \mathrm{SO}_{4}, 1: 1 \mathrm{H}_{2} \mathrm{SO}_{4}$ and 4:6 $\mathrm{H}_{2} \mathrm{SO}_{4}$ at 1 minute soaking time (Table 5).

\section{Discussions}

\subsection{Effect of Mechanical Scarification on Germination of Cuscuta campestris}

Mechanically scarified seed with sandpaper continuously gave higher germination percentage of the combined mean followed by gravel and the least from the unscarified seeds (control) though not significant. Probably, this showed that $C$. campestris seeds were more scarified with sandpaper than the rest of the mechanical treatments which had less potential of breaking the dormancy of the seed. Similarly, [7] reported that mature dodder seeds were induced to germinate by mechanical scarification with sandpaper. [9] also reported that total germination of Parkia biglobosa seeds mechanically scratched in gravels was $21.4 \%$ and no germination from the unscarified seeds (control).

Table 4. Interaction effects between tetraoxosulphate (VI) acid $\left(\mathrm{H}_{2} \mathrm{SO}_{4}\right)$ and soaking time on percentage germination of Cuscuta campestris at day 6 in Mean of Trials I and II.

\begin{tabular}{|c|c|c|c|}
\hline \multirow{2}{*}{ Treatment } & \multicolumn{3}{|c|}{ Soaking time (minutes) } \\
\hline & 1 & 3 & 5 \\
\hline Control & $3.37^{\mathrm{a}}$ & $3.28^{\mathrm{a}}$ & $2.38^{\mathrm{b}}$ \\
\hline 9:1 $\mathrm{H}_{2} \mathrm{SO}_{4}$ & $0.70^{\mathrm{d}-\mathrm{g}}$ & $0.60^{\mathrm{d}-\mathrm{g}}$ & $0.50^{\mathrm{d}-\mathrm{g}}$ \\
\hline $7: 3 \mathrm{H}_{2} \mathrm{SO}_{4}$ & $1.39^{c-e}$ & $0.60^{\mathrm{d}-\mathrm{g}}$ & $0.40^{\mathrm{d}-\mathrm{g}}$ \\
\hline 1:1 $\mathrm{H}_{2} \mathrm{SO}_{4}$ & $0.60^{\mathrm{d}-\mathrm{g}}$ & $1.19^{c-f}$ & $0.50^{\mathrm{d}-\mathrm{g}}$ \\
\hline 4:6 $\mathrm{H}_{2} \mathrm{SO}_{4}$ & $2.38^{\mathrm{b}}$ & $1.39^{\text {cee }}$ & $1.49^{\mathrm{cd}}$ \\
\hline $3: 7 \mathrm{H}_{2} \mathrm{SO}_{4}$ & $2.38^{\mathrm{b}}$ & $0.70^{\mathrm{d}-\mathrm{g}}$ & $0.90^{\mathrm{c}-\mathrm{s}}$ \\
\hline $2: 8 \mathrm{H}_{2} \mathrm{SO}_{4}$ & $1.10^{\mathrm{c-g}}$ & $0.40^{\mathrm{d}-\mathrm{g}}$ & $0.99^{\mathrm{c}-\mathrm{s}}$ \\
\hline $1: 9 \mathrm{H}_{2} \mathrm{SO}_{4}$ & $1.89^{\mathrm{bc}}$ & $1.19^{\mathrm{c}-\mathrm{f}}$ & $1.19^{\mathrm{c}-\mathrm{f}}$ \\
\hline \multicolumn{4}{|c|}{$\mathrm{SE}( \pm) 0.36$} \\
\hline
\end{tabular}

Table 5. Interaction effects between tetraoxosulphate (VI) acid $\left(\mathrm{H}_{2} \mathrm{SO}_{4}\right)$ and soaking time on percentage germination of Cuscuta campestris at day 9 in Mean of Trials I and II.

\begin{tabular}{|c|c|c|c|}
\hline \multirow{2}{*}{ Treatment } & \multicolumn{3}{|c|}{ Soaking Time (minutes) } \\
\hline & 1 & 3 & 5 \\
\hline Control & $45.34^{\mathrm{a}}$ & $37.70^{\mathrm{bc}}$ & $36.42^{\mathrm{bc}}$ \\
\hline 9:1 $\mathrm{H}_{2} \mathrm{SO}_{4}$ & $38.39^{b}$ & $23.12^{\mathrm{f}}$ & $25.80^{\text {ef }}$ \\
\hline $7: 3 \mathrm{H}_{2} \mathrm{SO}_{4}$ & $44.74^{\mathrm{a}}$ & $32.14^{\mathrm{cd}}$ & $36.31^{b c}$ \\
\hline $1: 1 \mathrm{H}_{2} \mathrm{SO}_{4}$ & $43.35^{\mathrm{a}}$ & $36.51^{\mathrm{bc}}$ & $30.16^{\mathrm{de}}$ \\
\hline 4:6 $\mathrm{H}_{2} \mathrm{SO}_{4}$ & $44.91^{\mathrm{a}}$ & $37.40^{\mathrm{bc}}$ & $37.90^{\mathrm{b}}$ \\
\hline $3: 7 \mathrm{H}_{2} \mathrm{SO}_{4}$ & $30.56^{\mathrm{de}}$ & $39.09^{\mathrm{b}}$ & $33.53^{\mathrm{cd}}$ \\
\hline $2: 8 \mathrm{H}_{2} \mathrm{SO}_{4}$ & $37.70^{\mathrm{bc}}$ & $26.99^{\mathrm{e}}$ & $36.61^{b c}$ \\
\hline $1: 9 \mathrm{H}_{2} \mathrm{SO}_{4}$ & $34.82^{\text {ce }}$ & $30.77^{d}$ & $27.68^{\mathrm{e}}$ \\
\hline \multicolumn{4}{|c|}{$\mathrm{SE}( \pm) 3.00$} \\
\hline
\end{tabular}




\subsection{Effects of Tetraoxosulphate (VI) Acid $\left(\mathrm{H}_{2} \mathrm{SO}_{4}\right)$ and Soaking Time on Germination of Cuscuta campestris}

At the end of the trials combined means showed that tetraoxosulphate (VI) acid treatment of 4:6 concentration significantly gave the highest $C$. campestris seeds germination compared with the control and the rest of the treatments. Combined mean for the time of soaking the seeds in tetraoxosulphate (VI) acid revealed that the seeds soaked for 1 minute had the highest germination of $C$. campestris compared with the 3 and 5 minutes treatments. This indicates that the longer the soaking time the seed coat is ruptured the faster rate of germination, however, prolonged immersion may be injurious to the seeds as the acid may rapture vital parts of the embryo. This is in line with the findings of [9] who reported that seeds of Parkiabiglobosa soaked in concentrated tetraoxosulphate (VI) acid $\left(\mathrm{H}_{2} \mathrm{SO}_{4}\right)$ for 3 minutes gave the highest germination of $50 \%$, but none of the seeds germinated after soaking for 5 minutes.

\section{Conclusion}

It can be concluded that tetraoxosulphate (VI) acid of 4:6 concentrations treatments has the potentiality to break dormancy of $C$. campestris seeds to germinate.

\section{References}

[1] Holm, L., Doll, J., Holm, E., Panch, J. and Herberger, J. (1979) World Weeds: Natural Historiesand Distribution. John Wiley \& Sons, New York, 1129 p.

[2] Gworgwor, N.A., Ndahi, W.B. and Chr. Weber, H. (2001) Parasitic Weed of North-Eastern Region of Nigeria: A New Potential Threat to Crop Production. The BCPC Conference: Weeds.

[3] Marambe, B., Wijesundara, S., Tennakoon, K., Peneniya, D. and Jayasinghe, C. (2002) Growth and Development of Cuscuta chinensis Lam. and Its Impact on Selected Crops. Weed Biology and Management, 2, 79-83. http://dx.doi.org/10.1046/j.1445-6664.2002.00051.X

[4] Lanini, W.T., Miranda-Sazo, M. and Goldwasser, Y. (2004) Management of Cuscuta in Tomato with Resistant Varieties and Herbicide. Proceeding of the 8th International Parasitic Weed Symposium, Durban, 34.

[5] Lanini, W.T. and Kogan, M. (2005) Biology and Management of Cuscuta in Crops. Cienciae Investigacion Agraria, 32, 165-179.

[6] Menlebrouck, K., Ameloot, E., Assche, J.A.V., Verheneyen, K., Hermy, M. and Baskin, C.C. (2008) Germination Ecology of the Holoparasite Cuscuta epithymum. Seed Science Research, 18, 25-34.

[7] Hutchson, J.M. and Ashton, F.M. (1979) Effect of Desiccation and Scarification on the Permeability and Structure of the Seed Coat of Cuscuta campestris. American Journal of Botany, 66, 40-46. http://dx.doi.org/10.2307/2442623

[8] Tingey, D.C. and Allred, K.R. (1961) Breaking Dormancy in Seeds of Cuscuta approximate. Weeds, 9, 429-436. http://dx.doi.org/10.2307/4040861

[9] Aliero, B.L. (2004) Effects of Sulphuric Acid, Mechanical Scarification and Wet Heat Treatments on Germination of Seeds of African Locust Bean Tree Parkia biglobosa. African Journal of Biotechnology, 3, 179-181.

[10] Gomez, K.A. and Gomez, A.A. (1984) Statistical Procedure for Agricultural Research. Wiley, New York.

[11] Duncan, N.G. and Hasketh, J.D. (1968) Net Photosynthesis Rates, Relative Growth Rate Leaf Number of 22 Cases of Maize and Eight Temperatures. Crop Science, 8, 670-674. http://dx.doi.org/10.2135/cropsci1968.0011183X000800060009x 